\title{
A clinical study on shodhananga snehapana with special reference to Samyak Snigdha Lakshana
}

\author{
Research Article
}

\section{Shweta Patil1*, Geeta Sathavane ${ }^{2}$}

1. Associate Professor, Department of Panchakarma, Dr. Rajendra Gode Ayurved College, Amravati, Maharashtra. 2. Associate Professor, Department of Rognidan evam Vikruti Vigyan,

Datta Meghe Ayurved College, Nagpur, Maharashtra.

\begin{abstract}
Snehana (internal oleation) is the major preparatory procedure to be performed before Shodhana (Biopurification).The entire procedure of Shodhana depends upon the proper mobilization of humors (Dosha) from peripheral circulation (Shakha) to intestinal circulation (Koshtha), which is achieved with the help of Snehana and Svedana. Oleation leads and decides total outcome of The Bio purification therapy; Hence in this study standard guidelines are applied for performing internal oleation in an effective manner to avoid Ayoga (insufficient use) and Atiyoga (excessive use) of Snehana. For that we start and increased dose of lipids in an appropriate manner considering Agni (power of digestion) and Koshtha (nature of bowels) of patients. The study was carried out on total 30 healthy volunteers undergoing Vasantik Vamana. Shodhananga Snehapana with Shuddha Ghrita was administered according to Agni and Koshtha of patients. Samyak snigdha Lakshanas were assessed using special scoring pattern. Statistical analysis using paired' $\mathrm{t}$ ' test were done. Onset of samyak snigdha lakshana occurs in sequence. Vatanuloman, Agnidipti, Gatra Mruduta, Klama, Snehodvega, Adhastat Sneha Darshana was seen in all patients; whereas, glani, Anga Laghava, Twak Snighdata were noted in less percentage of patients.
\end{abstract}

Key Words: Shodhananga Snehana, Samyak snigdha Lakshana, Snehana.Vamana Karma.

\section{Introduction}

Snehana (oleation) is a procedure mentioned under Shad Upakrama. (1) (Six type of treatment) which is being used independently for the promotion of health, cure of many diseases as well as a part of Shodhana (purification) as its Poorvakarma (preparatory procedure). Snehana (oleation) is an important preoperative procedure that has to be done before Vamana and Virechana. Proper Snehana (oleation) is essential for attainment of Samyak Shuddhi Lakshana. The careful daily assessment of oleation is very important for deciding further steps like sudation, emesis, or purgation. Any error in the assessment may lead to complications. The assessment of the outcome of oleation therapy is done on the basis of the symptoms of adequate oleation described as per classics.

\section{Objective}

To assess signs and symptoms of Samyak Snehana with various clinical parameters.

* Corresponding Author:

\section{Shweta Patil}

Associate Professor,

Department of Panchakarma,

Dr.Rajendra Gode Ayurved College, Amravati,

Maharashtra. India

Email Id: vdpatilshweta@gmail.com

\section{Materials and Methods Source of Data}

30 healthy volunteers willing to participate in the study were selected from OPD of Panchakarma department in Dr.Rajendra Gode Ayurved College, Amravati Maharashtra.

\section{Selection Criteria}

Total 30 patients were examined by randomized, open, prospective trial, irrespective of sex, religion, education, occupation, economic status.

\section{Inclusion Criteria}

- Patients who are clinically fit to undergo Snehapana as a Poorvakarma for Vamana.

- Age: 16 to 60 years.

- Sex-both the sex

\section{Exclusion Criteria}

- Clinically unfit for Vamana and Shodhananga Snehapana.

- Chronic debilitating disease.

- Malignant Hypertension.

- Pregnant ladies and lactating mothers

- Patient not willing for admission

- Patients having auto immune disorder

- Patients with infectious disease patient having IBS, gastric ulcer ulcerative colitis, pulmonary \& intestinal TB/AIDS/HbsAg. 
Shweta Patil et.al., A clinical study on shodhananga snehapana with special reference to Samyak Snigdha Lakshana

\section{Methodology}

30 healthy volunteers were assigned for Snehapana before undergoing Vamana. Detailed history, physical and mental examinations were done on the basis of specialized proforma designed for this purpose. They were also assessed on the basis of Agni and koshtha along with other criteria. Deepana and Pachana (2) were done by using Trikatu Churna $3 \mathrm{gm}$ (3) twice a day with lukewarm water for 5 days till the appearance of Niram Lakshana (4).on $6^{\text {th }}$ day in morning around $6 \mathrm{am}$. After praying god and Swastivachana non medicated ghee was given to the patient in an increasing pattern from $30 \mathrm{ml}$ to $250 \mathrm{ml}$ after assessing Jeerna Aahar Lakshana (clear belching and proper evacuation of bowels) (5) and Akshudhita Awastha (not feeling hungry). Patients were advised to take lukewarm water as Anupana. After the consumption of Ghee instruction was given to the patients not to take food until he/she feels hungry. The Snigdha Lakshanas were observed daily and were scored according to the Scoring pattern.

\section{Criteria for Assessment}

The following subjective parameters were considered for assessing Samyak Snigdha Lakshana.

Vatanuloman: It was assessed by Percussion and auscultation of abdomen and further confirm from patients for presence of this symptoms.

1. Upward movement of Vata with excessive belching and flatulence.

2. Mild flatulence and heaviness of abdomen

3. Proper evacuation of flatus, faces and urine and lightness in the abdomen

Agnidipti: It was assessed on the basis of the time of administration of Sneha (Oleaginous substance) and the feeling of appetite. For easy calculation, an understanding of agnidipti factor one standardized formula was accepted based on dose of sneha and time taken for digestion (6).

Agnibala index: $=\frac{(\text { Test dose })}{(\text { Given dose })} \times($ Time taken for digestion of ghee $)$

- Test dose- It is the small quantity of Snehana given on first day for the assessment of Agnibala

- Given Dose-It is the increasing quantity of Snehana has to be given after assessing the Agnibala by test dose.

Lesser the Agnibala index (A.B.I) more will be the Agnidipti.

1. A.B.I $>3$

2. A.B.I $=3$

3. A.B.I $<3$

\section{Snehodvega}

1. Alpa Snehdvesha still able to take ghee

2. Madhyam Snehdvesha by seeing, testing and smelling ghee but able to take ghee by force.

3. Bahu snehdvesha and refused to take the ghee.
Tvak Snigdhata/Gatrasnigdhata: It was assessed by drawing a line with pointed blunt object on the skin, if there is no scratch, it indicates Tvak Snigdhata.

1. Dryness of the skin

2. Softness of Skin

3. Proper oiliness of skin

\section{Purish Snigdhata/Adhastat sneha Darshan}

1. Dry and hard stool

2. Soft stool with fats

3. Only oily stools

\section{Klama/ Glani}

1. Enthusiastic

2. Reasonably active as usual

3. Tiredness without exertion

\section{Angalaghav}

1. Heaviness throughout the day

2. Mild lightness after digestion of Snehana

3. Feeling of complete lightness in the body throughout the day.

\section{Score pattern for samyak Snigdha Lakshana}

1. 17-21= Pravara Samyak Snigdh Lakshana

2. 13-17= Madhyam Samyak Snigdh Lakshana

3. 8-13= Heen Samyak Snigdh Lakshana

4. $\angle 8=$ Asnigdh Lakshana

\section{Criteria for assessment of Koshtha}

Routine Bowel Habit was considered for assessment of Koshtha as per the following features:

Frequency per day

1. Passing stool on alternate day

2. 1 time a day

3. 2 times a day

Consistency of stool

1. Hard stool

2. Soft, well formed

3. Loose, watery not well formed

Passing of stool

1. With more efforts \& unsatisfactory evacuation

2. With normal efforts \& satisfactory evacuation.

3. Without any effort \& satisfactory evacuation.

Feeling of urge of defecation

1. Not feeling any urge. Needs to take some stimulants like hot tea, warm water.

2. Feeling of urge within 10-30 minute of wake-up.

3 . Feeling of urge as wake up in morning.

Effect of taking hot milk, hot water etc. at night

1. No effect

2. Slightly loose but formed stool once.

3. Watery loose stool \& frequent.

Score

1. 1-5 implies - Kroora Koshtha

2. 6-10 implies - Madhyam Koshtha

3. 11-15 implies - Mridu Koshtha 
Assessment of $A g n i$

- No alteration-Tikshna Agni

- Mild /Inequitable alteration-Vishamagni

- Gross alteration- Mandagni

\section{Observations and Results}

Maximum patients were from 26 to 45 years age group. Among total patients, $66.67 \%$ of subjects were male and $33.33 \%$ were female. Religion wise distribution showed that maximum number of patients (93.3\%) were from Hindu community. Economic status wise distribution of patient shows that $66.67 \%$ patients were belonging to middle class. $80 \%$ patients were of Madhyama Sara and $63.3 \%$ of patients having Madhyama Samhana.

Table 1: Prakruti wise distribution of Patients

\begin{tabular}{|c|c|c|c|c|}
\hline & $\begin{array}{c}\text { No. of } \\
\text { Patients }\end{array}$ & $\begin{array}{c}\text { Percentage } \\
\%\end{array}$ & $\begin{array}{c}\text { Duration } \\
\text { required for } \\
\text { snehana }\end{array}$ \\
\hline \multirow{2}{*}{ Prakriti } & $\begin{array}{c}\text { Kapha } \\
\text { Vataj }\end{array}$ & 14 & 46.67 & 5-6 days \\
\hline $\begin{array}{c}\text { Pitta } \\
\text { vataj }\end{array}$ & 13 & 43.33 & $3-4$ days \\
\hline $\begin{array}{c}\text { Kapha } \\
\text { pittaj }\end{array}$ & 3 & 10 & $4-5$ days \\
\hline
\end{tabular}

Role of Snehana according to Prakruti reveals that maximum $46.67 \%$ of the subjects having Kapha vataj prakruti require 5-6 days to attain the Samyak snigdha Lakshana. Pitta vataj prakruti was observed in $43.33 \%$ of the subjects who took 3-4 days to get Samyak Snigdha Lakshana. Only $10 \%$ of subjects having Kaphapittaj Prakruti require 4-5 days to attain Samyak Snehana.

\section{Table 2: Agni wise distribution of Patients}

\begin{tabular}{|c|c|c|c|} 
Agni & $\begin{array}{c}\text { Total No. of } \\
\text { Patients }\end{array}$ & $\begin{array}{c}\text { Percentage } \\
\mathbf{( \% )}\end{array}$ & $\begin{array}{c}\text { Duration } \\
\text { required } \\
\text { for Snehana }\end{array}$ \\
\hline Vishmagni & 11 & 39.33 & $5-6$ days \\
\hline Madagni & 14 & 46.33 & $4-5$ days \\
\hline Teekshnagni & 5 & 20.33 & $3-4$ days \\
\hline
\end{tabular}

In this study, among the 30 subjects, Mandagni was observed in $46.33 \%$ of Patients who took 4-5 days to attain Samyak Snigdh Lakshana. 39.33\% of subjects having Vishmagni require 5-6 days to Snigdha Lakshana while only $20.33 \%$ of subjects having
Teekshnagni require 3-4 days to attain Samyak Snigdh Lakshana.

Table 3: Koshtha wise distribution of Patients

\begin{tabular}{|c|c|c|c|}
\hline Koshtha & $\begin{array}{c}\text { Total No. of } \\
\text { Patients }\end{array}$ & $\begin{array}{c}\text { Percentage } \\
\text { (\%) }\end{array}$ & $\begin{array}{c}\text { Duration } \\
\text { required } \\
\text { for Snehana }\end{array}$ \\
\hline Krura & 10 & 33.33 & $5-6$ days \\
\hline Madhyama & 13 & 43.33 & $4-5$ days \\
\hline Mrudu & 7 & 23.33 & $3-4$ days \\
\hline
\end{tabular}

Role of Koshtha In Snehana, revels that maximum $43.33 \%$ of subjects having madhyam Koshtha requires 4-5 days to attain Snigdha Lakshana, $33.33 \%$ of the subject having Krura Koshtha requires 5-6 days for Samyak Snehna. only 23.33\% of Subjects having Mrudu Koshtha requires 3-4 days to attain Samyak Snigdh Lakshana.

\section{Table 4: Samyak Snigdha Lakshana observed in 30 patients during the study}

\begin{tabular}{|l|c|c|c|c|}
\hline $\begin{array}{l}\text { Samyak } \\
\text { Snigdh } \\
\text { Lakshan }\end{array}$ & $\begin{array}{l}\text { No. of } \\
\text { pts }\end{array}$ & Mean & S.D. & Percentage \\
\hline Agnidipti & 26 & 1.4 & 0.8 & 86.67 \\
\hline Snehodvega & 28 & 1.8 & 0.4 & 93.33 \\
\hline $\begin{array}{l}\text { Tvak } \\
\text { snigdhata }\end{array}$ & 7 & 0.8 & 0.1 & 23.33 \\
\hline Vatanuloman & 27 & 1.6 & 0.6 & 90 \\
\hline $\begin{array}{l}\text { Adhastad } \\
\text { sneha } \\
\text { darshana }\end{array}$ & 30 & 2.0 & 0.0 & 100 \\
\hline Ghlani & 22 & 1.2 & 0.2 & 73.33 \\
\hline Klama & 26 & 1.4 & 0.8 & 86.67 \\
\hline Anglaghav & 4 & 0.6 & 0.2 & 13.3 \\
\hline
\end{tabular}

Observation related with mean score of Samyak Snigdha Lakshana with S.D. and percentage was on last day of Snehapana all subjects showed Purish snigdhata with mean score 2.0. Vatanuloman and Snehodvega shows in $90 \%$ and $93 \%$ of patients respectively with mean score of 1.8 , and 1.6 respectively. Whereas $86.67 \%$ subjects showed Klama Lakshana and Agnidipti with S.D. 1.4, 73.33\% subjects showed glani with S.D. 1.2. 23.33\% subjects noticed Tvak Snigdhata with mean score of 0.8 and only $13.3 \%$ subjects perceived Angalaghavata with mean score of 0.6 (S.D. \pm 0.2 ).

\begin{tabular}{|c|c|c|c|c|c|c|}
\hline $\begin{array}{c}\text { Initiation Of } \\
\text { samyak Snigdha } \\
\text { Lakshana }\end{array}$ & $\begin{array}{c}\text { Table 5: Summary of day wise percentage of signs and symptoms of Snehana } \\
\text { percentage of } \\
\text { volunteers }\end{array}$ & $\begin{array}{c}\mathbf{2}^{\text {sd }} \text { day } \\
\text { percentage of } \\
\text { volunteers }\end{array}$ & $\begin{array}{c}\mathbf{3}^{\text {rd }} \text { day } \\
\text { percentage of } \\
\text { volunteers }\end{array}$ & $\begin{array}{c}\mathbf{4}^{\text {th }} \text { day } \\
\text { percentage of } \\
\text { volunteers }\end{array}$ & $\begin{array}{c}\mathbf{5}^{\text {th }} \text { day } \\
\text { percentage of } \\
\text { volunteers }\end{array}$ & $\begin{array}{c}\mathbf{6}^{\text {th }} \text { day } \\
\text { percentage of } \\
\text { volunteers }\end{array}$ \\
\hline Vatanuloman & 80 & 84.67 & 94.3 & 96.6 & 97.2 & 87.3 \\
\hline Agnidipti & 100 & 98.3 & 85.2 & 82.2 & 87.6 & 78.1 \\
\hline Purish snigdhata & 0 & 0 & 0 & 13.33 & 53.46 & 33.33 \\
\hline Twak snigdhata & 0 & 0 & 0 & 26.1 & 86.33 & 33.3 \\
\hline klama & 0 & 0 & 0 & 13.34 & 27.23 & 34.67 \\
\hline Snehodveg & 0 & 0 & 0 & 23.3 & 46.67 & 33.34 \\
\hline Anglaghav & 31.3 & 14.4 & 12.1 & 0 & 0 & 0 \\
\hline
\end{tabular}


After assessing 30 patients, it was observed that the passage of flatulence was present in almost $80 \%$ patients from the day one. The nature of feces started changing in $13.33 \%$ patients from the fourth day. Feces were oleaginous in $53.46 \%$ of patients on fifth day and $33.33 \%$ on sixth day.. Maximum patients having Klama from $4^{\text {th }}$ day, $5^{\text {th }}$ and $6^{\text {th }}$ day. Snehodvega (Rejection to consume oleaginous substance) got initiated from the day four in $23.3 \%$ patients and it is maximum $46.67 \%$ on the fifth and sixth day.

Table 6: Maximum dose given on the last day of Snehapana 30 patients

\begin{tabular}{|c|c|c|}
\hline Max given dose on last day & $\begin{array}{c}\text { Total No of } \\
\text { Patients }\end{array}$ & $\%$ \\
\hline $\mathbf{1 0 0 - 1 5 0}$ & 3 & 10 \\
\hline $\mathbf{1 5 0 - 2 0 0}$ & 19 & 63.33 \\
\hline $\mathbf{2 0 0 - 2 5 0}$ & 7 & 23.33 \\
\hline
\end{tabular}

\section{Discussion}

Shodhanartha Snehapana (consumption of fats before the procedure of purification) has four fundamental purposes before the purification processes as follows -

- To attain the Vata nigraha and utklehsana of doshas by which they come from Shakha(tissue) to Kostha (digestive tract) there by facilitating the removal of Doshas from the body through Shodhana (purification) (7).

- To pacify the anticipated provocation of Vata after the purification processes (8).

- For providing strength to the body for bearing the stress of the purification processes (9).

- To get the proper Shodhana effect and prevent further complications.

The therapeutic action attributed to Shodhananga Snehapana by Caraka is 'Snehanam Sneha Vishyandam Mardava Kledakarakam' (10).This action is due to the their properties like Drava (liquid), Sukshma (minute), Sara (fluidity), Snigdha (unctuous), Pichhil (sticky), Guru(heavy), Sheetal (cold), Manda (slow), Mrudu (soft)(11). So, when they enter the circulation, the said properties start acting on various Dhatus and Srotas (channels). They convert solidified and stucked up Doshas into liquefied complex. This complex then starts gliding through the channels towards Koshtha. This process of liberation of doshas from channels and their travel towards koshtha is reflected through various signs and symptoms over the body. These are identified as "Samyka snigdha lakshanas".

Action of Sneha over the body was seen from the day one. Vatanulomana and Diptagni was the immediate sign present in the maximum patients on the day one. When Sneha Dravyas enters into the Annavaha srotas, due to its Snigdha Guna.

Anulomana of Apana Vayu occurred, which resulted in the good functioning of Apana Vayu and Pachaka Pitta and in turn Agnidipti was observed. Purisha Snigdhata was started to be observed from $3^{\text {rd }}$ day onwards. It suggests the gradual Snigdhata of Purishavaha Srotas, which will reach maximum by $7^{\text {th }}$ day.

During the digestion of oleaginous drugs due to their Guru (heavy to digest) property, gastro intestinal blood flow increases (post prandial or functional hyperemia) with decreased blood flow to the brain due to parasympathetic activity.(12) This gives the feeling of tiredness, i.e. Klama. This was present from the first day itself in all the patients for the whole period. This symptom gets corrected once the digestion process is completed.Twak Snigdhata reveals that Sneha has reached up to Rasa, Rakta, Mamsa and also Majja Dhatu (13)

At the end of the Snehapana course, when the body gets saturated with enough sneha and when it exceeds the limit of Agni Body starts rejecting it and the patient shows the sign named "Adhah staat sneha darshanam". So, from the above data it can be understood that the onset of Snehana Lakshana described by Caraka and other Acharyas are in the sequence of appearance. However, in this study the symptom of Twak Snigdhata is little difficult to achieve or may not appear in all the patients.

\section{Conclusion}

Snehapana should be done with well planned method by considering Agni,Koshtha and Prakruti of patients . It helps in deciding the dose and duration of Snehapana. All the symptoms of Samyak Snigdha Lakshnas were occurred sequentially as per classics.

\section{References}

1. Yadavaji Trikamaji Acharya.Charaka Samhita of Agnivesha revised by Charaka. Reprint edition.Varanasi; Chaukhamba Orientalia publishers; 2014. $120 \mathrm{P}$.

2. Tripathi B. Ashtang Hridayam of Vagbhata. Reprint Edition. Delhi; Chaukhamba Sanskrit Pratishthan publishers; 2007. 188p.

3. Tripathi B. Sharangdhar Samhita of Aracharya Sharangdhar. 6th edition. Varanasi; Chaukhambha,Surbharti Prakashan; 2005. 179 p.

4. Tripathi B. Ashtang Hridayam of Vagbhata. Reprint Edition.Delhi; Chaukhamba Sanskrit Pratishthan; 2007. $187 \mathrm{p}$

5. Yadavaji Trikamaji Acharya. Madhav Nidan of

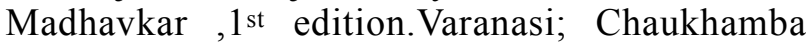
Orientalia publishers;2010. 91p.

6. Vasant P. Principles and Practice of Panchakarma. 1st edition.Karnataka: Atreya Ayurveda Publications; 2011. 104 p.

7. Yadavaji Trikamji Acharya.Charak Samhita of Agnivesha. Reprint edition.Varanasi; Choukhamba Prakashan; 2009. 25 p.

8. Yadavaji Trikamji Acharya.Charak Samhita of Agnivesha. Reprint edition.Varanasi; Choukhamba Prakashan; 2009.25 p..

9. Kunte, Navare, Paradkar HS. Ashtanga Hridayam of Vagbhat . 7th edition. Varanasi; Chaukhamba Orientalia publishers; 1982. 
10. Yadavaji Trikamji Acharya. Charak Samhita of Agnivesha. Reprint edition. Varanasi; Choukhamba Prakashan; 2009. 120 p.

11. Yadavaji Trikamji Acharya,Charak Samhita of Agnivesha. Reprint edition .Varanasi; Choukhamba Prakashan; 2009.120 p.
12. Arthur C. Guyton, John E. Hall. Textbook of Medical Physiology. 11ed. Pennsylvania; Elsevier Inc; 2002.page. 819.

13. Sharma P V. Sushruta Samhita of Acharya Sushruta. 1st edition. Varanasi; Chaukhambha Orientalia publishers; 1976. 356. 